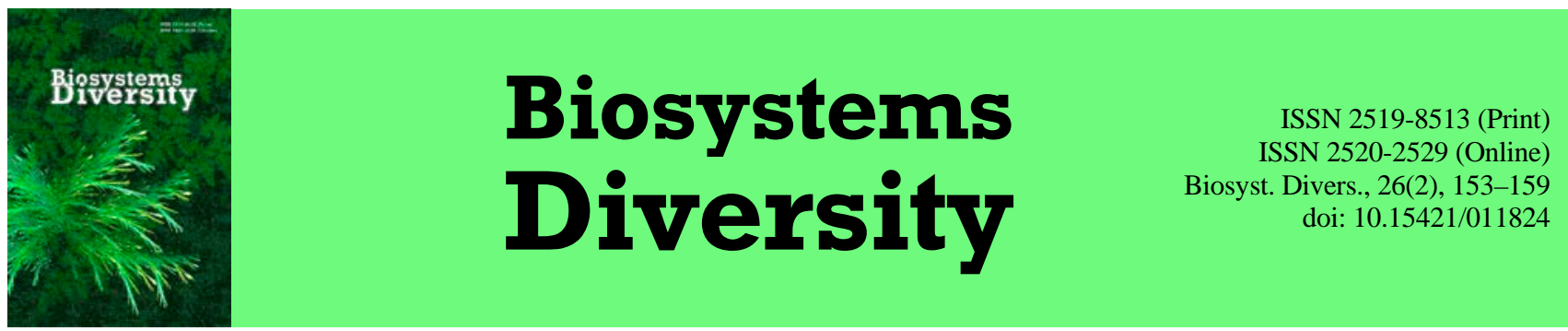

\title{
Distribution of poultry ectoparasites in industrial farms, farms, and private plots with different rearing technologies
}

\author{
A. P. Paliy*, A. M. Mashkey*, N. V. Sumakova*, A. P. Paliy** \\ *National Scientific Center “Institute of Experimental and Clinical Veterinary Medicine”, Kharkiv, Ukraine \\ **Kharkiv Petro Vasylenko National Technical University of Agriculture, Kharkiv, Ukraine
}

Article info

Received 19.04.2018

Received in revised form 08.05 .2018

Accepted 12.05.2018

National Scientific Center "Institute of Experimental and Clinical Veterinary Medicine”, Pushkinska st., 83, Kharkiv, 61023, Ukraine. Tel. +38-066-225-34-34 E-mail: paliy.dok@gmail.com

Kharkiv Petro Vasylenko National Technical University of Agriculture, Moskovs'kyj ave. 45, Kharkiv, 61000, Ukraine. Tel.: +38-057-732-79-22
Paliy, A. P., Mashkey, A. M., Sumakova, N. V., \& Paliy, A. P. (2018). Distribution of poultry ectoparasites in industrial farms, farms, and private plots with different rearing technologies. Biosystems Diversity, 26(2), $153-159$. doi:10.15421/011824

One of the problems in growing and keeping poultry, both in industrial and farm and kitchen garden environments is ectoparasites, which are responsible for lowering the productivity of poultry and causing economic losses. The study of the prevalence and diagnosis of bird ectoparasites on poultry farms with different maintenance technologies is important for the further development of integrated methods for combating them. Our research was conducted during 2006-2017 in 16 regions of Ukraine and the Autonomous Republic of Crimea. In total, 38 poultry farms specializing in egg production with poultry kept in battery cages, 18 poultry houses specializing in egg production with poultry kept on the floor and more than 150 farm and kitchen garden poultry houses for keeping chickens, turkeys, quails, guinea fowl and pigeons were examined. We found that, both with battery cages and when poultry are kept on the floor in poultry farms, the most common ectoparasites are chicken mites (Dermanyssus gallinae), which causes the disease of dermanyssiosis. It was determined that the extensivity of the invasion was, on average, from $56 \%$ to $80 \%$. Also, in the chickens and turkeys, mallophages (Menopon gallinae, Menacanthus stramineus), which cause mallophagoses, were detected, and the extensivity of the invasion ranged from $27 \%$ to $45 \%$. In farms and kitchen gardens where chickens, guinea fowl and quails were kept, the number of chicken mites in $1 \mathrm{~g}$ substrate was more than a thousand live mites, in dovecotes chicken mites were found in $50 \%$ to $100 \%$ of nests. In chickens and turkeys, besides the chicken mite, bird lice were found. In chickens, extensivity of invasion of $M$. gallinae, M. stramineus, Lipeurus variabilis, ranged from $15 \%$ to $22 \%$, in turkeys, extensivity of invasion of $M$. gallinae and $M$. stramineus ranged from $16 \%$ to $25 \%$. The scaly leg mite (Knemidocoptes mutans), which causes the disease knemidocoptiasis ("lame leg"), was detected in incubating hens over the age of two years, the extensivity of the invasion ranged from $5 \%$ to $7 \%$. It was established that in poultry farms, both in battery cages and when the birds were kept on the floor, the main ectoparasite in chickens, guinea fowl and quail is red chicken mite (D. gallinae), and on poultry farms and kitchen gardens in addition to the chicken mite, three types of bird lice (M. gallinae, M. stramineus, L. variabilis) and K. mutans were found.

Keywords: red chicken mite; pulmonary diseases; dermanyssiosis; mallophages; knemidocoptiasis

\section{Introduction}

One of the priority directions of agricultural development in Ukraine is the poultry industry. Modern poultry farming combines a high level of mechanization and automation of production (Wheelock, 1990; Sabluk, 2009). At the same time, it is the most knowledge-intensive sector of livestock breeding, which is capable of radically improving the food security of our state in a short term (Ionov et al., 2012; Dayk, 2016).

The increased concentration of poultry, creation of optimal conditions of temperature and humidity in the premises, specific ways of removing litter, penetration of water into the mixed feed water and a number of other factors provide favourable conditions for the year-round development and existence of ectoparasites (Firaol et al., 2014; Flochlay et al., 2017; Paliy et al., 2018).

Common pathogens of entomoses and acarosids of chickens in poultry farms in Ukraine and around the world are a large group of invertebrates that are numerous in species composition and very diverse in their taxonomy, which belong to Arthropoda phylum, Insecta and Arachnoidea classes (Akbaev et al., 2008). Chickens are parasitized by red poultry mites or chicken mites Dermanyssus gallinae (De Geer, 1778); they belong to the Parasitiformes order, the Gamasoidea superfamily, the Dermanyssidae family (Westheide et al., 1996; Mehlhorn
\& Piekarski, 2002); by ticks Ornithodoros sylviarum (Canestrini \& Fanzago, 1877) and Ornithonyssus bursa (Berlese, 1888) of the Dermanyssus genus of the Macronyssidae family of the Mesostigmata suborder (Bregetova, 1956; Denmark \& Comroy, 2012); by Knemidocoptes mutans and $K$. laevis mites, the suborder Acariformes, Sarcoptoidea superfamily, the Sarcoptidae family (Vasilevich \& Akbaev, 2011); by fowl tick Argas persicus (Oken, 1818) Parasitiformes order, the Ixodida order, Argas genus (Filipova, 1966); chewing lice (Mallophaga) classified (Redi, 1668) belonging to the Menoponidae family of the monotypic superfamily Menoponoidea, Phthiraptera order (Menacanthus stramineus (Nitzsch, 1818), Goniocotes hologaster, Lipeurus heterographus, Eomenacanthus stramineus, Menopon gallinae (Linnaeus, 1758), Menacanthus cornutus) (Akbaev, 2010); bed bugs Cimex lectularius (Linnaeus, 1755), which are classified in the Hemiptera order, Cimicidae family, Cimex genus (Mullen, 2010); Echidnophaga gallinacea fleas (Westwood, 1875) from the Pulicidae family; sometimes the poultry is attacked by Oriental rat fleas Xenopsylla cheopis (Rothschild et al., 1870) which belong to the Siphonaptera order (Murillo \& Mullens, 2016).

The red poultry mite $D$. gallinae is one of the most dangerous blood feeding parasites of chickens. This mite is found in different climatic zones of our country (Mashkey et al., 2013). In scientific lite- 
rature, parasitism by red poultry mites in Europe was described more than 20 years ago. Parasites are a threat not only to the health of poultry, but also to workers in the poultry industry (Windhorst, 2017). Around the world, it is registered in the regions up to $60^{\circ}$ of northern latitude, where it is a significant threat to chickens. The red poultry mite is broadly distributed across the USA, countries in Africa, Europe, the Middle East and Asia (Makert et al., 2016; Sparagano et al., 2014).

Ectoparasites are a problem in poultry rearing, in industrial as well as in farm and kitchen garden conditions (Puff, 1999). An examination of poultry houses in private holdings in Southern California found poultry mites D. gallinae - 55\%, Menacanthus stramineus chewing lice - 5\%, Goniocotes gallinae - 3\%, Lipeurus caponis - 20\%, Menopon gallinae - 15\%, Cuclotogaster heterographs - 5\%; Echidnophaga gallinacea fleas - 20\%, parasitic mites Ornithonyssus sylviarum - 15\% and Knemidocoptes mutans - 10\% (Murillo \& Mullens, 2016). According Rezaei et al. (2016), during the examination of poultry houses in Colombia, D. gallinae mites were detected in 8.5\% of households. Also, ectoparasites such as Menacanthus stramineus, M. gallinae, Cuclotogaster heterographus, Goniocotes gallinae, Ornithonyssus bursa, K. mutans were found. Parasitization by D. gallinae poultry mites has also been reported in poultry farms in Brazil (Tucci et al., 2008; Salifou et al., 2013). The distribution of $D$. gallinae poultry mites was studied in poultry farms in four districts of Palestine (Nablus, Tulkarem, Tubi and Jenin). The largest poultry mite infestation was observed in Tulkarem region - 47.3\%, which is explained by the hot and humid climate in the area. The high level of distribution of the mite is related to violation of sanitary standards for poultry keeping in the region (Othman et al., 2012).

The red poultry mite is widely spread in Sweden in all types of poultry farms. The intensity of the invasion there is more than $73 \%$. The biggest problem is the presence of bloody spots on the eggshell, scratching with beak and death of birds (Gunnarsson, 2017). A high distribution of $D$. gallinae poultry mites has been reported in poultry farms in Poland, which is up to $100 \%$ (Cencek, 2003). He also mentions that in the mid-1990s, the poultry mite D. gallinae was found mainly in cellular systems of chicken maintenance. Over the recent years, the mite has been found increasingly frequently when birds are kept on the floor.

A number of researchers have come to the following conclusions: the genetic flexibility of $D$. gallinae, its constant invasion of large poultry farms can be the potential for parasitization of other species of hosts (cat, dog, rabbits, horses and rodents). Personnel of poultry farms can also be at risk of infestation. Expansion of trade and economic ties and the consequences of climate change are expected to contribute to a widening of the range of hosts (George et al., 2015).

Mashkey \& Zaharov (2002), Girich \& Popova (2004) reported D. gallinae parasitism on the territory of Ukraine. In the territory of the Poltava region, four species of Mallophaga have been identified in chickens: three species of the Menoponidae family (Menopon gallinae, Menacanthus stramineus, $M$. cornutus) and one species of the Goniodidae family (G. hologaster) (Hizhnya, 2013).

Therefore, it should be noted that in Ukraine, as well as in 26 countries of the world, both with high and low development of poultry rearing, the problem of $D$. gallinae parasitism is quite relevant.

The study of the distribution and diagnosis of ectoparasitic diseases of poultry in poultry farms with different maintenance technologies is important for the further development of integrated methods against them (Meyer-Kühling et al., 2007; George et al., 2008; Sylejmani et al., 2016). That is why the purpose of our research was to study the ectoparasites of poultry in industrial, farm, and kitchen garden conditions with different maintenance technologies for the further development of effective methods against the parasites.

\section{Materials and methods}

The life of ectoparasites as pathogens of diseases directly depends on environmental conditions typical for the geographic region, season of the year, etc. Therefore, to study the significance of ectoparasites as pathogens of arachnoentomosis, predicting their abundance, as well as proper planning of disinsection measures, we took into account the most important seasonal phenomena in their life. Among the latter are:

- periods of mass appearance of ectoparasites in premises and on poultry;

- appearance of separate stages (phases) of development of ectoparasites (beginning, peak number, end);

- periods of birth of young imagoes (beginning, maximum abundance, end);

- periods of mass attack on birds by ectoparasites.

We also took into account: the type of premises, the system of maintaining the birds, temperature regime, humidity, light and sanitary condition of the poultry.

To detect chewing fleas, birds at the age of three months were examined. For this purpose, the areas of the uropygial gland, cloaca, back, lower and lateral parts of the body as well as the head were carefully examined. Special attention during the inspection was given to weakened, exhausted birds with clearer areas of alopecia. The diagnosis was made on the basis of the presence of parasites on the body of the poultry. Malophages (chewing lice) were differentiated from sucking lice by the presence of a gnawing apparatus and the shape of the head (the head of chewing lice is significantly larger than the chest).

For the diagnosis of knemidocoptiasis ("scaly foot"), skin scrapes were taken from the birds` legs. The material was investigated by mortal methods (finding dead mites) and by vital methods (detection of live mites, larvae and eggs). Mortal methods were used for the initial diagnosis. Vital methods are aimed at finding live Acari, which is important not only for the final diagnosis, but also for assessing the effectiveness of the treatment. The selected material was analysed immediately or not later than 72 hours after scraping.

For the detection of pathogens of syringophilosis caused by Syringophilus bipestinatus which parasitize in the feather calamus, we examined birds from the age of (5-7) months, which had improperly formed contour feathers. For the final diagnosis, feathers which fell out were examined. The feather calamus was opened by curved incision, the contents were transferred to a slide glass, and (1-2) drops of glycerol was added for clarification during passing the light through it. The obtained mixture was analyzed under a binocular magnifying glass at $12 \times 4$ or under a microscope with a small magnification for detecting Acari. For the detection of red poultry mites, we collected Acari from the bodies of birds and from various constructions in the premises where poultry were kept, as well as samples of substrate.

Acari were collected from chickens in poultry houses in the night by the light of a lantern. Acari were most often found on the head at the comb and eyelids, on the neck, under the wings and in the folds of the skin. Acari were taken with fine tweezers and those which moved freely by a brush moistened in alcohol or a thin wooden stick with a sharpened end.

In poultry houses, the collecting was conducted at any time of day. The Acari were brushed off onto a sheet of white paper from cages, conveyor belts, feeders, barrier gum and eggs. From inaccessible places, the collecting was carried out by hitting the constructions with a stick, also samples of fodder dust and feces were taken. The number of Acari on the premises was determined by counting parasites per $10 \mathrm{~cm}^{2}$ of the area of structures.

To detect a temporary parasite of chickens, fowl tick Argas persicus (Argasidae family), we performed the selection as with collecting red poultry mite according to the methodoligical recommendations (Mashkey et al., 2010). The collected material was preserved in 70\% alcohol for further determination of the species composition of parasites in the laboratory.

Before the beginning of laboratory studies, samples of ectoparasites were prepared. Before the genus identification, the collected ectoparasites were killed with chloroform or ethyl acetate. The arthropods were sorted in Petri dishes, classified into groups: mallophages, Gamasina and Argasidae. During the identification process, we estimated the number of ectoparasites by species in poultry and on the premises, if necessary, we recorded physiological parameters (females with eggs, stages of blood digestion, phases of development). During identification or in the process of sorting the ectoparasites, they were grouped into 
samples. They included a certain number of individuals selected from one place or the same type of objects. In the test tubes, we indicated the collection number and date. One sample included 20-30 (not more than 50) individuals. The mites were sorted separately by development phases: one sample included blood sucking females - up to 3; hungry - up to 30 ; nymphs sucking blood - up to 15 ; hungry - up to 50 ; the larvae which sucked blood - up to 30 .

The diagnosis of ectoparasitic diseases of chickens was complex: based on epizootological data, symptoms of the disease, detection of arthropods on the body of birds and in places of localization of parasites in the premises were confirmed. The ectoparasite species were identified in the laboratory using light microscopy and verified with identification guides (Bregetova, 1956; Filippova, 1966).

\section{Results}

Populations of ectoparasites were found during the examination of premises of poultry farms, farms and private plots in different regions of Ukraine. Identification of the ectoparasitic species demonstrated that the most distributed is the red poultry mite (D. gallinae) (Table 1, and Fig. 1).

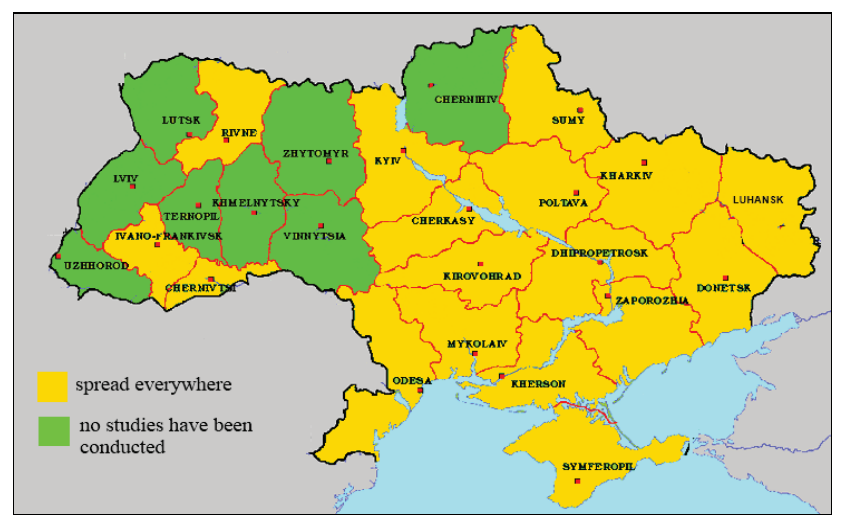

Fig. 1. Distribution of red poultry mite (D. gallinae) in different regions of Ukraine

The data presented in Table 1 show that the red poultry mite (D. gallinae) is the commonest in industrial, farm and domestic plots of different types. On some farms, there were observed mixed infestations (red poultry tick, chewing lice). Indicators of infestation of chewing lice were higher on farms and private plots. Of the flies, the commonest species were M. domestica L. and Drosophila F., which indicates an unsatisfactory veterinary and sanitary condition.

Industrial poultry farms. Battery cage housing of poultry. On industrial poultry farms, poultry houses are mostly made of concrete, in some farms there are old wooden constructions. The old wooden premises have 6 batteries, each battery contains 3-4 tiers of cages, concrete premises have 6-7 batteries with 3-5 tiers of cages. In each cage, 6 to 10 hens are kept. Access to feeders and drinkers is free. Light is artificial. The temperature in the poultry houses in winter is retained by the body temperature and flow heating. According to our observations, the average temperature in poultry houses was $17-18{ }^{\circ} \mathrm{C}$ in the winter, and $25-30{ }^{\circ} \mathrm{C}$ in the summer. The development cycle of the poultry mite lasts 15-18 days in the winter, and 7-10 days in the summer. The highest number of mites in the summer was observed in the southern regions of Ukraine (Kherson, Zaporozhye, Odessa, Mykolayiv oblasts and Crimea) - up to $100 \%$.

During the examination of concrete poultry houses for hens (Kharkiv, Poltava, Kiev, Rivne regions) where the sanitary condition of the premises is satisfactory, the air temperature in the summer 23$25^{\circ} \mathrm{C}$, humidity $60 \%$, once a week, we carried out wet cleaning with a Kercher cleaning device, in the poultry houses of the 4th and 5th tiers of the battery, a large number of poultry mites was found, which concentrated on the upper tiers, causing difficulty in counting and taking measures against them.

During the examnation of pedigree flock of laying hens (Kharkiv region) kept in cages with cocks, we found chewing lice which were found under the wings and in the area of the cloaca. The pedigree cocks were purchased at a poultry farm in Poltava region, where poultry was kept on the floor.

Table 1

Species of arthropods found in industrial premises,

farms and domestic plots in Ukraine

\begin{tabular}{|c|c|c|}
\hline \multirow[b]{2}{*}{ Species composition of arthropods } & \multicolumn{2}{|c|}{ Poultry farms } \\
\hline & $\begin{array}{c}\text { industrial } \\
\text { type }\end{array}$ & $\begin{array}{c}\text { farms and } \\
\text { domestic plots }\end{array}$ \\
\hline \multicolumn{3}{|c|}{ Keeping poultry in cages } \\
\hline \multicolumn{3}{|c|}{ Chicken } \\
\hline \multicolumn{3}{|c|}{ Acarina (Parasitiformes, Gamasoidea, Dermanyssidae } \\
\hline Dermanyssus gallinae (De Geer, 1778) & ++++ & ++++ \\
\hline \multicolumn{3}{|c|}{ Mallophaga of Phthiraptera order, Menoponoidea superfamily, Menoponidae famil } \\
\hline Menopon gallinae (Linnaeus, 1758) & + & ++ \\
\hline Menacanthus stramineus (Nitzsch, 1818) & - & + \\
\hline \multicolumn{3}{|c|}{$\begin{array}{c}\text { Insecta - insects of Diptera order, Muscidae family } \\
\end{array}$} \\
\hline Musca domestica (Linnaeus, 1758) & ++ & +++ \\
\hline Musca autumnalis (De Geer, 1776) & - & + \\
\hline Fannia scalaris (Fabricius, 1794) & - & + \\
\hline Drosophila (Fallén, 1823) & + & + \\
\hline \multicolumn{3}{|c|}{ Quails } \\
\hline Dermanyssus gallinae De Geer & - & +++ \\
\hline Musca domestica L. & - & ++ \\
\hline Drosophila F. & - & + \\
\hline \multicolumn{3}{|c|}{ Keeping poultry on the floor } \\
\hline \multicolumn{3}{|c|}{ Laying hens } \\
\hline Dermanyssus gallinae De Geer & +++ & ++++ \\
\hline Musca domestica L. & ++ & +++ \\
\hline Drosophila F. & + & + \\
\hline \multicolumn{3}{|c|}{ Acarina - mites of Acariformes order, Sarcoptoidea superfamily, Sarcoptidae family } \\
\hline Knemidocoptes mutans (Fürstenberg, 1870) & - & + \\
\hline \multicolumn{3}{|c|}{ Chicken meat breeds } \\
\hline Musca domestica L. & + & ++ \\
\hline Drosophila F. & + & + \\
\hline \multicolumn{3}{|c|}{ Turkeys } \\
\hline Dermanyssus gallinae De Geer & - & - \\
\hline Menacanthus stramineus N. & + & ++ \\
\hline Musca domestica L. & + & + \\
\hline \multicolumn{3}{|c|}{ Guinea Fowl } \\
\hline Musca domestica L. & - & + \\
\hline Fannia scalaris F. & - & + \\
\hline \multicolumn{3}{|c|}{ Pigeon houses } \\
\hline Dermanyssus gallinae De Geer & - & ++ \\
\hline Musca domestica L. & - & ++ \\
\hline Fannia scalaris F. & - & + \\
\hline Drosophila F. & - & + \\
\hline
\end{tabular}

Notes: "++++" - 75-100\% the distribution of ectoparasites; "+++" - 50

75\%; "++" - 25-50\%; "+" to 25\%; "-" - ectoparasites are absent.

In the poultry houses with unsatisfactory sanitary condition and poor ventilation, the population of the mite was over $20 \%$. Mites in food dust mixed with down and feathers formed large groups - up to 10,000 ticks and more. On metal constructions, parasites gathered in large colonies after sucking blood. In such groups, individuals of all age groups are present. On boards of $0.324 \mathrm{~m}^{2}$ area between cages, 120 to 3,000 individuals gathered. Per $10 \mathrm{~cm}$ of barrier rubber, we found over 2,000 mites, on eggs - 7 to 10 individuals. In 35-40 grams of chicken litter which was taken off the platforms, we found 25 to 30 mites in the microscope view.

Thus, according to our observations, the main places of localization of red poultry mites are as follows: elements of battery cages, coupling elements of the constructions, conveyor belts, eggs, dust mixed with feather down, chicken litter.

The red poultry mite (D. gallinae) is a nest-tunnel parasite. Mites attack the birds only during feeding, and after becoming sated, leave the birds and hide in cracks, litter, dust, etc. Mites have negative phototaxis, so they attack usually in the dark. However, at high numbers of mites (84-100\%), we observed D. gallinae in large amounts on structures, eggs and poultry in the daytime. External examination of corpses of brown Hyline hens of 242-550 days age in Mykolayiv oblast revealed anemia of the comb skin and ear lobes, thickening of 
eyelid skin, and skin of the body having signs of dermatitis. Flight feathers were absent. On the entire surface of the body of the dead birds and in the nasal passages, we found live mobile $D$. gallinae sated with blood. Intensity of mite infestation was $167.80 \pm 27.89$ specimens/individual. Bacteriological examination of skin scrapes revealed pathogenic microflora (Staphylococcus spp., Streptococcus spp.).

In poultry farms where mites leave red spots on egg shells, the eggs were not presentable and were used on melange, which caused economic losses to the farms. According to our observations in poultry farms where the Acari infestation was over $50 \%$, the laying ability decreased to $20 \%$, and the death of poultry equaled $10 \%$.

Also, we observed an attack of poultry mite on the operators of the poultry houses (Kharkiv region, AR of Crimea). The workers had rash on their body, itching, and raised temperature.

As a result of the conducted studies, it was established that in the poultry farms with battery cage type of maintenance, for both laying hens and hatchlings, the extensivity of the invasion of red poultry mite was $20 \%$ to $100 \%$, and the number varied depending on the season of the year (Table 2). The infestation intensity of chewing lice in the poultry farms ranged $15-25 \%$ and the main outbreak of the disease was observed in autumn.

Table 2

The number of $D$. gallinae in premises for keeping laying hens in the poultry farms of Ukraine at different seasons of the year

\begin{tabular}{cclcc}
\hline $\begin{array}{c}\text { No } \\
\text { farm }\end{array}$ & $\begin{array}{c}\text { Maintenance } \\
\text { technologies }\end{array}$ & $\begin{array}{c}\text { Period of } \\
\text { study }\end{array}$ & $\begin{array}{c}\text { Number of D. gallinae } \\
\text { in room, ind./m }\end{array}$ & $\begin{array}{c}\text { EI of D. gallinae } \\
\text { mite, } \%\end{array}$ \\
\hline \multirow{2}{*}{1} & cages & spring & $2550 \pm 293$ & 98 \\
& & summer & $7352 \pm 121$ & 100 \\
2 & cages & winter & $32 \pm 4$ & 20 \\
& & summer & $700 \pm 49$ & 95 \\
3 & cages & spring & $285 \pm 20$ & 84 \\
4 & cages & winter & $72 \pm 5$ & 20 \\
5 & cages & aummer & $878 \pm 48$ & 86 \\
6 & cages & summer & $2330 \pm 330$ & 100 \\
7 & cages & summer & $945 \pm 129$ & 95 \\
8 & cages & autumn & $3310 \pm 470$ & 100 \\
9 & cages & winter & $195 \pm 44$ & 100 \\
10 & cages & spring & $1250 \pm 178$ & 20 \\
11 & cages & summer & $3250 \pm 403$ & 100 \\
12 & cages & summer & $2600 \pm 256$ & 100 \\
13 & cages & summer & $3252 \pm 402$ & 100 \\
14 & cages & winter & $107 \pm 18$ & 100 \\
15 & cages & spring & $126 \pm 18$ & 30 \\
16 & cages & summer & $2335 \pm 333$ & 25 \\
17 & cages & spring & $126 \pm 18$ & 100 \\
\hline
\end{tabular}

It was determined that the maximum number of $\mathrm{D}$. gallinae was $7,352 \pm 121 \mathrm{specimen} / \mathrm{m}^{2}$, at EI $-100 \%$. The minimum number of mites in premises was $32 \pm 4$ specimens $/ \mathrm{m}^{2}$, at $\mathrm{EI}-20 \%$. The average number of poultry mites in the winter months was $717 \pm 376$ specimens $/ \mathrm{m}^{2}$, at $\mathrm{EI}-36 \%$. In the spring months, the number of mites was $1,052 \pm 557$ specimens $/ \mathrm{m}^{2}$, at EI - 77\%. In the summer months, the number of mites on average equaled $1,859 \pm 1,137$ specimens $/ \mathrm{m}^{2}$, at EI - 67\%. Thus, the poultry farms for egg production studied in different regions of Ukraine were found to be unfavourable and infested with $D$. gallinae. At the same time, $80.3 \%$ of them had a high degree of Acari infestation of the premises, $14.4 \%$ - average degree. Only $5.3 \%$ of the examined farms proved to be favourable for acariasis and particularly for poultry mites. Also, in the premises and on the territory of poultry farms, the flies $M$. domestica L., F. caniculeris L. and Drosophila F. were found, which indicates an unsatisfactory veterinary and sanitary condition.

Keeping poultry on the floor. In poultry farms (with laying hens, broilers, turkeys), on deep unchanged litter, the severity of the extensivity of invasion of red poultry mites among laying hens was $25-86 \%$; among turkeys, mainly chewing lice were found with an intensity of invasion of 25-30\% (Table 3).

Flies Musca domestica L., Fannia caniculeris L., Drosophila funestris L. were identified only in territory around poultry houses.
Table 3

The number of $D$. gallinae mites, $M$. gallinae and $M$. stramineus mallophages in poultry rearing facilities on ground litter in poultry farms of Ukraine at different seasons of the year

\begin{tabular}{|c|c|c|c|c|c|}
\hline $\begin{array}{l}\text { No } \\
\text { farm }\end{array}$ & $\begin{array}{l}\text { Period } \\
\text { of study }\end{array}$ & $\begin{array}{c}\text { Number } \\
\text { of } D \text {. gallinae mites } \\
\text { in room, ind. } / \mathrm{m}^{2}\end{array}$ & $\begin{array}{l}\text { EI of chicken } \\
\text { mite } \\
\text { D. gallinae, \% }\end{array}$ & $\begin{array}{c}\text { II of } \\
\text { mallophages, } \\
\text { ind./bird }\end{array}$ & $\begin{array}{c}\text { EI of } \\
\text { mallophages, } \\
\%\end{array}$ \\
\hline \multicolumn{6}{|c|}{ Chickens } \\
\hline 1 & winter & $126 \pm 18$ & 25 & - & - \\
\hline 2 & spring & $107 \pm 18$ & 30 & - & - \\
\hline 3 & summer & $878 \pm 48$ & 86 & - & - \\
\hline 4 & autumn & $109 \pm 18$ & 30 & - & - \\
\hline \multicolumn{6}{|c|}{ Broiler } \\
\hline 5 & winter & - & - & - & - \\
\hline 6 & spring & - & - & - & - \\
\hline \multicolumn{6}{|c|}{ Turkey } \\
\hline 7 & winter & - & - & $127 \pm 18$ & 25 \\
\hline 8 & spring & - & - & $109 \pm 18$ & 30 \\
\hline 9 & summer & - & - & $124 \pm 18$ & 25 \\
\hline 10 & autumn & - & - & $108 \pm 18$ & 30 \\
\hline
\end{tabular}

The highest number of $D$. gallinae mites when poultry are kept on deep unchanged litter, among hens in summer was $878 \pm 48$ speci$\mathrm{men} / \mathrm{m}^{2}$, in winter and autumn, the number decreased $-126 \pm 18$ specimen $/ \mathrm{m}^{2}$. In the premises for keeping turkeys, red poultry mites were not found, and the number of mallophages varied 25 to 30\%. In the premises with five week old broilers no ectoparasites were found.

Poultry on farms and private plots. Since 2013, the number of chicken mites in homestead farms and farms has increased due to purchase of young and laying hens in the market, which were from poultry farms with dermanyssiosis infestation.

Poultry on farms. In the farms, apart from the high number of chicken mites (up to thousand vital mites per $1 \mathrm{~g}$ of substrate), we found the following chewing lice: $M$. gallinae, $M$. stramsneus, their extensivity of invasion was 20-35\%; and also identified the following flies (Diptera: Muscidae): M. domestica L., M. autumnalis L., F. caniculeris L., D. funestris.

The largest farm examined is located in Vasyshcheve urban-type settlement. The research was conducted during the summer period. There are three premises for poultry on the territory of the farm. In the first room, 400 Lohman Brown egg-laying hens were kept. The premises were made of wood-concrete constructions, insulated with glass wool. The hens were kept in three-tier metal battery cages. Sanitary conditions of the premises were unsatisfactory, litter was cleaned once in 5-10 days. The room temperature was $26-28^{\circ} \mathrm{C}$, air humidity was $60 \%$. At the farm, death of the poultry was periodically recorded. During the examination of the poultry, we found anemia of the mucous membranes, comb and ear lobes; reddening of the skin, loss of feathers and scratching with beak. During the examination of the birds, we found $D$. gallinae chicken mites, EI was $100 \%$. The number of mites in the poultry house was $856 \pm 5$ specimens $/ \mathrm{m}^{2}$. No ectoparasites were found during the examination of hens `eathers for Syringophilosis (81 hens) and Mallophaga (50 hens). The second room had 200 five week old broiler chickens. The sanitary condition of the room was satisfactory. There were no ectoparasites found on the poultry and in the poultry houses. The third room was temporarily cleared of poultry due to parasitization by $D$. gallinae. The number of mites in the poultry house was $713 \pm 76$ specimens $/ \mathrm{m}^{2}$. According to the medical history, the introduction of ectoparasites occurred in the winter of 2013 from a poultry farm located in the Zmiyiv district of Kharkiv oblast, when equipment was purchased.

Poultry on private plots. Poultry houses on private plots practically do not differ one from another. Chickens are kept in wood-concrete rooms and in foraging areas in the yard. The sanitary condition of the poultry houses was, in most cases, satisfactory. It should be noted that $41.7 \%$ of private plots farms with poultry mites had a high degree of invasiveness on their premises, the average degree equaling 58.3\%. According to research results, the most massive concentration of chicken mites was recorded in the lower part of the cages. Mites were also found in accumulation of spiders'webs and various detritus in the corners of 
cages or in nests, on the ceiling and walls. According to our observations, the main way mites penetrate to poultry houses is through purchase of infested birds, contaminated equipment and egg containers. Also it should be mentioned that on the private plots where the owners raised laying hens themselves (from day-old chicks), the chicken mite was not found.

On private plots, apart from the high number of chicken mites, the poultry was parasitized by chewing lice such as $M$. gallinae, $M$. stramineus, and feather lice such as $L$. variabilis mallophagas. The highest number of $M$. gallinae was recorded from January to July. A steep decrease in the number of this species was noted in August September, and from November their number increased. The intensity of the invasion of the hens by this species of chewing lice ranged $15 \%$ to $25 \%$ in the summer period and $25 \%$ to $30 \%$ in the springwinter period. Smaller numbers were recorded for $M$. stramineus chewing lice. A reduction in numbers was observed from May to August, their number in poultry increased again in September, and reached its maximum in December - March. The intensity of the infestation of chickens with $M$. stramineus in the summer was $6 \%$ to $12 \%$, and $25 \%$ to $30 \%$ in winter and spring. The lowest number was observed for L. variabilis, which was observed in the spring. The intensity of infestation with this species ranged from $2 \%$ to $3 \%$.

Locations of species of chewing lice are specific. M. gallinae was found on the skin and on the feathers of the lateral surfaces of the body, along the lower part of the shaft. In January and February, massive breeding of larvae occurred, which localized on the skin of the stomach and under the birds` wings. $M$. stramineus was found on the skin of stomach, under the wings and under the tail near the fovea externa cloacalis. In conditions of maximum number, the parasites were observed on all parts of the body of chickens. In June, when the temperature reached $30-35^{\circ} \mathrm{C}$, the lice were more often found on the comb, wattle and near the beak. $L$. variabilis were found on the lower surface of the first row feathers of wings and between sulci near the beak.

As a result of massive infestation, the birds were observed to experience severe itching, scratching, cutting with beak and dermatitis, which was followed by loss of feathers, all of which lead to exhaustion. At the same time, reduction in fertility by $3-5 \%$ and weight loss were noted. As a result of observations, it was recorded that adults suffered the worst. The birds scratched their skin and feathers for hours. This was observed during the moult, when insects and their larvae were on young feathers. The birds lost feathers on the stomach, back, head and neck.

An examination of 156 heads of birds in 3 yards in Dnipropetrovsk oblast revealed $M$. gallinae, equaling 75 to 85 individuals per chicken. Chewing lice were found on the skin of the stomach, under the wings and under the tail near the fovea externa cloacalis. There was a severe itching, combing of the skin, which was followed by feather loss. Also, there was a decrease in fertility and weight loss.

Also, in the private plots, we found $K$. mutans mites among laying hens. The birds were over two years old, it was kept in dark and dirty premises. Infestation on legs was recorded below the hock joint with the formation of thickening of the limb in the form of "scaly foot", which is characteristic of only this disease.

No mites (Syringophilus bipestinatus) causing syringophilosis were found. Generalized data on the number and species composition of arthropods that occur in industrial, farm and private plot poultry premises are presented in Table 4.

According to the results of the examination of more than 300 premises and 3,350 birds, it was determined that the main ectoparasitological disease in the territory of Ukraine is dermanyssiosis infestation, its share is $85.6 \%$, and a high percentage of dermanyssiosis is related to the spread of $D$. gallinae. The rarest recorded diseases were infestation with knemidocoptosis, its share was 3.5\%. Mallophaga infestations were recorded for different technologies of poultry keeping, its share equaled $21.1 \%$, but the pathogens of mallophagoses occur more often when poultry are kept on the floor.

\section{Discussion}

Sources from the literature report that the red poultry mite is a significant threat to poultry in many parts of the world, including the
United States, Europe, Japan and China. The level of infestation in France is up to 56\%, in the United Kingdom - 60\%, Denmark - 65\%. In Kosovo, $50 \%$ of poultry farms are invaded by red poultry mite (Afrim et al., 2011; Chu et al., 2015; George et al., 2015).

According to experts` estimates, in Ukraine, $50 \%$ to $60 \%$ of poultry farms are invaded by red poultry mites. The consequences of chicken mite infestation are as follows: $2 \%$ to $15 \%$ reduction of fertility on average, depending on the invasion level in hen houses, increase in mortality of poultry to $5 \%$, (red spots on the shell), decrease in food energy of eggs by 5-10\%. Economic losses, according to the estimates of European poultry farmers, equal 0.29 euro per chicken as a result of declining fertility and 0.14 euro per specimen due to measures against red poultry mites.

\section{Table 4}

The number of ectoparasites in farms and homestead farms in Kharkiv region

\begin{tabular}{|c|c|c|c|c|c|c|}
\hline No & Settlement & $\begin{array}{l}\text { Number } \\
\text { of birds }\end{array}$ & $\begin{array}{l}\text { Number of } \\
\text { D. gallinae } \\
\text { mites in } \\
\text { room, ind } / \mathrm{m}^{2}\end{array}$ & $\begin{array}{c}\text { EI of mite } \\
\text { D. gallinae, } \\
\%\end{array}$ & $\begin{array}{c}\text { II of } \\
\text { mallopha- } \\
\text { ges, } \\
\text { ind./bird }\end{array}$ & $\begin{array}{c}\text { EI of } \\
\text { mallopha- } \\
\text { ges, \% }\end{array}$ \\
\hline 1 & Horoshev & 18 (chickens) & $1893 \pm 142$ & 100 & - & - \\
\hline 2 & o urban- & 60 (chickens) & $825 \pm 60$ & 100 & - & - \\
\hline 3 & $\begin{array}{l}\text { type } \\
\text { settlement }\end{array}$ & 30 (chickens) & - & - & - & - \\
\hline 4 & Vasechev & 80 (chickens) & $73 \pm 7$ & 80 & - & - \\
\hline 5 & $\begin{array}{l}\text { o urban- } \\
\text { type } \\
\text { settlement }\end{array}$ & 85 (chickens) & $95 \pm 3$ & 100 & - & - \\
\hline 6 & & 140 (quails) & $52 \pm 12$ & 74 & - & - \\
\hline 7 & Verbivka & 50 (chickens) & $80 \pm 7$ & 80 & - & - \\
\hline 8 & village & 15 (guinea fowl) & - & - & - & - \\
\hline 9 & & 30 (turkeys) & - & - & $20 \pm 3$ & 45 \\
\hline 10 & & 50 (quails) & $84 \pm 5$ & 95 & - & - \\
\hline 11 & & 50 (chickens) & $317 \pm 25$ & 100 & - & - \\
\hline 12 & & 30 (turkeys) & - & - & $21 \pm 3$ & 45 \\
\hline 13 & Balakliya & 150 (pigeons) & $38 \pm 6$ & 45 & - & - \\
\hline 14 & & 30 (chickens) & $165 \pm 26$ & 100 & - & - \\
\hline 15 & & 50 (chickens) & $80 \pm 7$ & 80 & - & - \\
\hline 16 & & 20 (chickens) & - & - & $20 \pm 3$ & 45 \\
\hline
\end{tabular}

Note: The data presented in Table 4 indicate that in the examined poultry houses, circulation of $D$. gallinae was found among laying hens, quails and pigeons, and chewing lice were found on turkeys, with an intensity of infestation of $20 \pm 3$ specimens/bird. No ectoparasites were found on guineafowl.

According to the results of monitoring studies carried out in 16 regions of Ukraine and the Autonomous Republic of Crimea, involving poultry in battery cages on the floor in industrial premises, farms and private plots, the commonest ectoparasite of chickens is the red poultry mite (D. gallinae). In the poultry farms with battery cage type of maintenance, both with laying hens and young birds, the extensivity of invasion of red poultry mite was $20 \%$ to $100 \%$. With birds kept on deep unchanged litter, the extensivity of the invasion ranged from $25 \%$ to $86 \%$ and the abundance of the parasites varied depending on season. According to George et al. (2015), the number of chicken mites was higher on 52-week-old laying hens than on young birds. According to the results of monitoring studies, it was determined that the commonest ectoparasite of chickens kept both in battery cages and on the floor is the red poultry mite (D. gallinae). Foreign researchers point out that, as the poultry keeping systems change in many parts of the world, $D$. gallinae is likely to become more widespread and difficult to control (Sparagano et al., 2014).

High numbers of chicken mites in poultry farms can be caused by several factors. Red poultry mites have a short development cycle (Marangi et al., 2012; George et al., 2015). According to our data, old wooden chicken coops and old equipment provide more shelter for mites, and also complicate cleaning of the poultry houses. Also, with poor ventilation, the number of chicken mites increases. In Sweden $63 \%$ of poultry producers are concerned that $D$. gallinae may have a strong impact on the health of chickens, egg quality, and human health (George et al., 2015; Gunnarsson, 2017). According to our observations in poultry farms, where number of mites equaled over $50 \%$ 
on the eggshells, there were red spots on the egg shells, eggs were not presentable and were used for melange. Egg-laying decreased to $20 \%$, and death of birds was $10 \%$. Also, we observed attack of chicken mites on the operators of poultry houses. Workers had rashes on the body, itching, raised temperature. Dermanyssus gallinae tends to breed again after insectoacaricide treatment, as well as to spread through workers at poultry farms and equipment (Oines \& Brännström, 2011; Marangi et al., 2012). We can presume that it is very difficult to completely eliminate mites in poultry farms. However, $65 \%$ of manufacturers of the egg industry noted that compliance with all technological regulations for operating, timely cleaning of premises ensure that the number of parasites is kept low (Sigognault et al., 2017).

In the course of the analysis of the distribution of ectoparasites in industrial farms, farms and private plots with different technologies of maintenance, it was found that the causes of invasion are: old wooden premises, old equipment, no adherence to microclimate parameters (humidity, high temperature in summer, poor ventilation); the presence of mechanical carriers (staff, synanthropic birds, mouse-like rodents etc.) which move from one poultry house to another, allowing the parasite to spread throughout the poultry farm; also the sale of laying hens and eggs from farms attacked by parasites due to repeated use of uncleaned egg containers.

The biological peculiarities of the red poultry mite such as descreet living, abilility to exist without food for a long time, rapid completion of the development cycle often lead to an outbreak of infestation among poultry (chickens, turkeys, quail, guineafowl, pigeons) in poultry farms. These data coincide with the results of studies by other researchers (Hobbenaghi et al., 2012; Collgros et al., 2013; Makert et al., 2016).

\section{Conclusions}

According to the results of the conducted monitoring studies, it has been found that, both with poultry kept in battery cages and on the floor in industrial poultry farms, the commonest ectoparasite is the chicken mite (D. gallinae) which causes dermanyssiosis infestation with the extensivity of invasion, on the average, $20 \%$ to $100 \%$. Also chickens and turkeys were found to have chewing lice (Menopon gallinae, Menacanthus stramineus) which cause mallophagoses, extensivity of invasion of which ranged $27 \%$ to $45 \%$. In the farms where chickens and quails were kept in battery cages, the intensity of infestation of red poultry mites was $74 \%$ to $100 \%$. On private plots, besides the chicken mite, the number of which in $1 \mathrm{~g}$ of substrate was up to one thousand vital mites, the chickens harboured chewing lice (M. gallinae, M. stramineus, Lipeurus variabilis), with the extenivity of the invasion equalling $15 \%$ to $22 \%$, turkeys were found to have M. gallinae, $M$. stramineus at infestation extensivity $16 \%$ to $25 \%$. Pigeons kept on private plots were found to have chicken mites, and the intensity of invasion was $45 \%$. Knemidocoptes mutans which causes knemidocoptiasis ("scaly foot") was found on laying hens older than two years, and the extensiveness of the invasion ranged from $5 \%$ to $7 \%$. It was proved that ectoparasites spread rapidly when veterinary and sanitary norms and regulations are not adhered to, when mechanical carriers of ticks are present (staff, synanthropic birds, mouse-like rodents etc.) and when there is repeated use of uncleaned egg containers.

\section{References}

Afrim, H., Kurtesh, S., Skender, M., Behlul, B., Fatgzim, L., Avni, R., Rezart, P., Hess, C., Hess, M., \& Sparagano, O. (2011). Dermanyssus gallinae in layer farms in Kosovo: A high risk for salmonella prevalence. Parasites and Vectors, 4(1), 136.

Akbaev, M. S., Vodyanov, A. A., Kosminkov, A. I., Yatusevich, A. I., Pashkin, P. I., \& Vasilevich, F. I. (2008). Parazitologiya i invazionnyye bolezni zhivotnyh [Parasitology and invasive diseases of animals]. Kolos, Moscov (in Russian).

Akbaev, M. S. (2010). Vidovoy sostav i sezonnaya chislennost' pukhoperoyedov-vozbuditeley mallofagoza kur [Species composition and seasonal abundance of Mallophaga on chickens]. Veterinarya, 10, 131-145 (in Russian).

Bregetova, N. G. (1956). Gamazovyye kleshchi. Kratkiy opredelitel' [The gas mites. A brief identification guide]. AN USSR, Moscov (in Russian).
Cencek, T. (2003). Prevalence of Dermanyssus gallinae in poultry farms in Silesia Region in Poland. Bulletin of the Veterinary Institute in Pulawy, 47, 465-469.

Chu, T. T., Murano, T., Uno, Y., Usui, T., \& Yamaguchi, T. (2015). Molecular 158 epidemiological characterization of poultry red mite, Dermanyssus galli8 nae, in Japan. Journal of Veterinary Medical Science, 77(11), 1397-1403.

Collgros, H., Iglesias-Sancho, M., Aldunce, M. J., Expósito-Serrano, V., Fischer, C., Lamas, N., \& Umbert-Millet, P. (2013). Dermanyssus gallinae (chicken mite): An underdiagnosed environmental infestation. Clinical and Experimental Dermatology, 38(4), 374-377.

Dayk, O. T. (2016). Stan ta napryamky rozvytku pidpryyemstv haluzi ptakhivnytstva [Status and directions of development of poultry industry enterprises]. Scientific herald of the Lviv National University of Veterinary Medicine and Biotechnology named after S. Z. Gzhytsky, 18(2), 58-61 (in Ukrainian).

Denmark, H. A., \& Comroy, H. L. (2012). Tropical fowl mite, Ornithonyssus bursa (Berlese) (Arachnida: Acari: Macronyssidae). IFAS Extention.

Filipova, N. A. (1966). Fauna SSSR. Paukoobraznyye. Argasovyye kleshchi (Argasidae) [Fauna of the USSR. Arachnida. Argasidae (Argasidae)]. Nauka, Moscov. Vol. 4(3). (in Russian).

Firaol, T., Dagmawit, A., Askale, G., Solomon, S., Morka, D., \& Waktole, T. (2014). Prevalence of ectoparasite infestation in chicken in and around Ambo Town, Ethiopia. Veterinary Science and Technology, 5(4), 189.

George, D. R., Finn, R. D., Graham, K. M., Mul, M. F., Maurer, V., Moro, C. V. \& Sparagano, O. A. E. (2015). Should the poultry red mite Dermanyssus gallinae be of wider concern for veterinary and medical science? Parasites and Vectors, 8, 178.

George, D. R., Guy, J. H., Arkle, S., Harrington, D., De Luna, C., Okello, E. J., Shiel, R. S., Port, G., \& Sparagano, O. A. (2008). Use of plant-derived products to control arthropods of veterinary importance: A review. Annals of the New York Academy of Sciences, 1149, 23-26.

Girich, A., \& Popova, L. (2004). Yak pozbavyty kurey vid klishchiv [How to get rid of ticks from chickens ]. Health of Animals and Medicine, 6, 12 (in Ukrainian).

Gunnarsson, E. (2017). Poultry red mites in Swedish laying hen flocks - occurrence and efficacy to a selection of acaricides. Agronomprogrammet, Husdjur.

Hizhnya, L. U. (2013). Poshyrennya malofahoziv kurey u hospodarstvakh Poltavs'koyi oblasti [Distribution of mallophages in chickens in farms of the Poltava region]. Bulletin of the Poltava State Agrarian Academy, 2, 173174 (in Ukrainian).

Hobbenaghi, R., Tavassoli, M., Alimehr, M., \& Shokrpoor, S. (2012). Histopathological study of the mite biting (Dermanyssus gallinae) in poultry skin. Veterinary Research Forum, 3(3), 205-208.

Ionov, I. A., Tereschenko, O. V., \& Katerinich, A. A. (2012). Perspektyvna prohrama "Rozvytok haluzi ptakhivnytstva do 2020 roku" [Perspective program “Development of poultry industry till 2020”]. Effective Poultry Farming, 10, 12-22 (in Ukrainian).

Makert, G. R., Vorbruggen, S., Krautwald-Junghanns, M. E., Voss, M., Sohn, K., Buschmann, T., \& Ubert, S. (2016). A method to identify protein antigens of Dermanyssus gallinae for the protection of birds from poultry mites. Parasitology Research, 115(7), 2705-2713.

Marangi, M., Morelli, V., Pati, S., Camarda, A., Cafiero, M. A., \& Giangaspero, A. (2012). Acaricide residues in laying hens naturally infested by red mite Dermanyssus gallinae. PloS One, 7(2), e31795.

Mashkey, A. M., Sumakova, N. V., \& Sirenko, O. S. (2010). Metody vidboru prob chlenystonogyh (klishhiv, komah) dlja diagnostyky ektoparazytoziv svijs'koi' ptyci [Methods of sampling arthropods (ticks, insects) for the diagnosis of ectoparasitoses of the bird's own habit]. IEKVM, Kharkiv (in Ukrainian).

Mashkey, A., Sumakova, N., \& Sirenko, E. (2013). Poshyrennya zbudnykiv ektoparazytarnykh zakhvoryuvan' sil's'kohospodars'koyi ta sviys'koyi ptytsi v lisostepoviy zoni Ukrayiny ta AR Krym [Distribution of pathogens of ectoparasitological diseases of agricultural and poultry in the forest-steppe zone of Ukraine and the Autonomous Republic of Crimea]. Veterinary Medicine: Interagency Thematic Scientific Collection, 99, 144-147 (in Ukrainian).

Mashkey, I., \& Zaharov, A. (2002). Ektoparazyty ptyts' v fermers'kykh i prysadybnykh hospodarstvakh Krymu [Ectoparasites of birds in farm and household farms of the Crimea]. Veterinary Medicine: Interagency Thematic Scientific Collection, 80, 423-428 (in Ukrainian).

Mehlhorn, H., \& Piekarski, G. (2002). Grundriss der Parasitenkunde. Spektrum Akad. Verlag, Berlin.

Meyer-Kühling, B., Heine, J., Müller-Lindloff, J., \& Pfister, K. (2007). Epidemiology of Dermanyssus gallinae and acaricidal efficacy of phoxim 50\% in alternative housing systems during the laying period of hens. Parasitology Research, 101, 1-12.

Mullen, G. R. (2010). Medical and veterinary entomology. Academic Press, Boston.

Murillo, A. C., \& Mullens, B. A. (2016). Diversity and prevalence of ectoparasites on backyard chicken flocks in California. Journal of Medical Entomology, 53(3), 707-711. 
Oines, O., \& Brännström, S. (2011). Molecular investigations of cytochrome C oxidase subunit I (COI) and the internal transcribed spacer (ITS) in the poultry red mite, Dermanyssus gallinae, in Northern Europe and implications for its transmission between laying poultry farms. Medical and Veterinary Entomology, 25(4), 402-412.

Othman, R. A., Abdallah, J. M., \& Abo-Omar, J. (2012). Prevalence of the red mite (Dermanyssus gallinae) in layer flocks in four districts in Northern West Bank, Palestine. Open Journal of Animal Sciences, 2(2), 106-109.

Paliy, A. P., Sumakova, N. V., Paliy, A. P., \& Ishchenko, K. V. (2018). Biological control of house fly. Ukrainian Journal of Ecology, 8(2), 230-234.

Rezaei, F., Hashemnia, M., Chelechale, A., Seidi, S., \& Gholizadeh, M. (2016) Prevalence of ectoparasites in free-range backyard chickens, domestic pigeons (Columba livia domestica) and turkeys of Kermanshah province, west of Iran. Journal of Parasitic Diseases, 40(2), 448-453.

Ruff, M. D. (1999). Important parasites in poultry production systems. Veterinary Parasitology, 84(3-4), 337-347.

Sabluk, P. (2009). Agrarian market development in Ukraine: Problems and prospects. Economics and Sociology, 2(1a), 23-27.

Salifou, S., Offoumon, O. T., Gouissi, F. M., \& Pangui, L. J. (2013). Endogenous recipes for controlling arthropod ectoparasites of domestic poultry. Revista Brasiliera de Parasitologia Veterinaria, 22(1), 119-123.

Sigognault Flochlay, A., Thomas, E., \& Sparagano, O. (2017). Poultry red mite (Dermanyssus gallinae) infestation: A broad impact parasitological disease that still remains a significant challenge for the egg-laying industry in Europe. Parasites and Vectors, 10, 357.

Sparagano, O., George, D. R., Harrington, D. W. J., \& Giangaspero, A. (2014) Significance and control of the poultry red mite, Dermanyssus gallinae. Annual Review of Entomology, 59, 447-466.

Sylejmani, D., Musliu, A., Ramadani, N., Sparagano, O., \& Hamidi, A. (2016) Associations between the level of biosecurity and occurrence of Dermanyssus gallinae and Salmonella spp. in layer farms. Avian Diseases, 60(2), 454-459.

Tucci, E. C., Prado, A. P., \& Araújo, R. P. (2008). Development of Dermanyssus gallinae (Acari: Dermanyssidae) at different temperatures. Veterinary Parasitology, 155(1-2), 127-132.

Vasilevich, F. I., \& Akbaev, M. S. (2011). Knemidokoptoz kur i mery bor'by s nim [Knemidokoptosis of chickens and measures to combat it]. Poultry and Poultry Products, 1, 53-56 (in Russian).

Westheide, W., \& Rieger, R. (1996). Spezielle Zoologie. Erster Teil: Einzeller und Wirbellose Tiere. Gustav Fischer Verlag, Stuttgart, Jena, New York.

Wheelock, V. (1990). Poultry: Current problems, future prospects. Nutrition and Food Science, 90(3), 20-21.

Windhorst, H. W. (2017). The EU egg industry in transition. Dynamics in the egg industry between 2010 and 2015. International Egg Commission Special Economic Report. International Egg Commission, London. 